УДК: 003.349(=163.41)»1914/1918»

$811.163 .41 » 1914 / 1918 »$

DOI: 10.18485/belic_slv.2016.1.ch20

Милош Ковачевић

\title{
СРПСКИ ЈЕЗИК И ЋИРИЛИЦА У ТОКУ ПРВОГА СВЈЕТСКОГ РАТА
}

\section{1. ПРОГОНИ СРПСКЕ ЋИРИЛИЦЕ И СРПСКОГ ЈЕЗИКА ПОСЛИЈЕ САРАЈЕВСКОГ АТЕНТАТА}

Непосредно послије Сарајевског атентата на Франца Фердинанда ситуација за босанскохерцеговачке Србе, а нешто касније и за све остале Србе, постала је несносно тешка. Мјесец дана послије атентата на Франца Фердинанда скоро сви образовани Срби из Босне и Херцеговине нашли су се у неком од затвора (од којих су најпознатији Добој и Арад) прво као таоци, а потом и као прави заробљеници.

Осим бројних судских процеса против српске интелигенције, затим вјешања и погубљења у пограничним крајевима, одвођења у таоце, логоре и интернацију, затим забране рада свих српских школа, листова и политичких организација, аустроугарска управа ишла је даље у сатирању српског националног бића. Тако су се на удару нашли и српски језик и његово писмо - српска ћирилииа ${ }^{1}$. „Прве мјере које су предузете у Монархији након избијања рата биле су потискивање ћирилице из јавне употребе. Тако је већ 3. октобра 1914. Земаљска влада у Хрватској укинула учење ћирилице у јавним основним школама. Наредбом школским властима од 5. новембра 1914. Земаљска влада у Загребу укинула је назив хрватски или српски језик и промијенила га у хрватски језик. Назив хрватски или српски језик за Владу је одједанпут постао опасност по 'државно-правни значај хрватског језика'. Новом наредбом Владе од 3. јануара 1915. у Хрватској је ћирилица укинута и у раду администрације” (Окука 2005: 95).

Стање је било још горе у Босни и Херцеговини, гдје је „антисрпско расположење добијало све званичније обрисе не само у практичном дјеловању власти него и у тежњама да се оно и санкционише путем језика и у одредбама о језику. (...) Генерал Саркотић и министар рата

${ }^{1} \mathrm{O}$ томе је, консултујући велики број докумената најисцрпније писао М. Окука (2005), чија анализе овдје под цитатима и преносимо. 
Ернест Корбатин били су упорни у настојању да убиједе Беч о потреби забране ћирилице у Босни и Херцеговини. Корбатин је у септембру 1915. тражио да се забрани не само ћирилица него и даља употреба назива српско-хрватски те да се поново уведе ранији назив земаљски језик (Landessprache). За њега је назив српски, у било којем облику и било којој комбинацији употријебљен, велеиздајнички (Окука 2005: 95-97). Цар се сагласио са укидањем ћирилице у Босни и Херцеговини, тако да је 10. новембра 1915. издата Наредба Земаљске владе у Сарајеву о употреби ћирилице. У њој је, између осталог, стајало и сљедеће:

a) Све босанскохерцеговачке власти: уреди и заводи употребљаваће у писаном српско-хрватском саобраћају само латиницу.

b) У свим земаљским наставним заводима са српско-хрватским наставним језиком, употребљаваће се само латиница.

c) И књиге у Народним основним школама штампане ћирилицом, имају се одмах замијенити књигама штампаним латиницом.

d) Ученици српско-православне вјере првог разреда 'одмах морају да престану да уче ћирилицу'. Ученици ћирилицу могу 'употребљавати само у настави вјеронауке, а учење тога писма препушта се наставницима вјеронауке"' (Окука 2005: 97-98).

Уз забрану ћирилице, „током 1914. и 1915. године, Земаљска влада са генералом Стјепаном Саркотићем на челу укинула је Уредбу о аутономији цркве и школе у Босни и Херцеговини, назив цркве је из српско-православна промијенила у источно-православна" (Томашевић 2011:13-14). Тако је свуда гдје је то било могуће као неподобан одстрањиван термин „српски”.

Забрана ћирилице није се, међутим, ограничила само на Хрватску и Босну и Херцеговину. Када је окупирала Србију и Црну Гору, Аустроугарска је у објема 1916. забранила ћирилицу у јавној употреби. Завладавши свим државама у којима је живио српски народ, Аустроугарска је у свима њима њима најприје укинула ћирилицу сматрајући је основном српском идентитетском карактеристиком.

Након окупације Црне Горе 1916. године „аустријска власт, наредбом генералног гувернера Виктора Вебера [бр. Е 1873 ех 16. Ž. К. од 18. септембра 1916] забрањује употребу ћирилице у школама, установама и поштанском саобраћају, а из школских програма искључује народне епске и патриотске пјесме, као и предмет Српска историја. Наиме, 'из програма је одстрањено све што се односило на Србију’” (Матовић 2013: 26).

Аустроугарске власти нису укинуле у Црној Гори само ћирилицу, него су у наставним плановима и програмима за основну школу из на- 
зива предмета избацили атрибут „српски”. Тако је „српски језик окупатор замијенио матерним језиком, српску историју - историјом, ирквенословенско читане - читанем, пјеване је уклоњено (и свјетовно и ирквено) итд." (Матовић 2013: 32).

\section{2. ОКУПИРАНА СРБИЈА}

У тешким тренуцима одступања, влада и Врховна команда донијеле су 25. новембра 1915. године одлуку о повлачењу до албанске обале. „Берлин, Беч и Софија доживели су пораз Србије ујесен 1915. године као тријумф сопственог оружја, који је требало војно, политички и економски искористити. Немачки цар Вилхелм II истицао је у данима победе како Србија 'мора сасвим да нестане'. У круговима блиским Фрањи Јосифу били су одлучни у ставу да не треба допустити 'да било шта остане од суверене Србије” (Радојевић/Димић 2014: 199). А најбитније је било сломити „морални отпор својих противника” и подстаћи „разлике у менталитетима, језику, вери и националним осећањима” (Радојевић/ Димић 2014: 229).

Послије окупације Србије дошло је до несугласица између Аустроугарске и Бугарске како направити диобу територија. План разграничења је, у складу са интересима саме Немачке, направио фелдмаршал фон Макензен. Тако су „под немачким утицајем, две стране 1. априла 1916. године потписале уговор који је утврдио демаркациону линију између аустроугарске и бугарске команде.

Аустроугарска окупациона управа у своме се раду држала начела „да Србију треба разорити. Окупационим подручјем се управљало помоћу уредаба, а не закона. Националне институције су укинуте. Званична преписка са окупаторским властима вршена је искључиво латиницом ${ }^{2}$, а у званичним актима, наредбама, решењима, прописима, објавама и преписци спровођена је кроатизација српског језика. Чиновништву је у упутствима налагано да поступа сурово, 'како би Српство било сломљено и његова снага била уништена за што дуже време.' Војним окупационим властима сугерисано је да 'најчвршћом руком' и с 'безобзирном строгошћу' гуше сваки отпор и побуну” (Радојевић/Димић 2014: 202).

Неколика мјесеца након окупације аустријске власти су на свом дијелу окупиране Србије забраниле употребу ћирилице, као писма које је сматрано дијелом српског националног идентитета, и препреком остварења

${ }^{2}$ Сва курзивна истицања у цитатима, ако се не даје друкчија напомена, накнадна су, тј. наша -МК. 
цивилизацијског искорака Срба. Одлуку о забрани ћирилице у јавној употреби донио је Војни генерални гувернеман за Србију 12. јуна 1916. године (в. Ђорђевић 2014: 7). Аустроугарска је, наиме, сматрала да у Хабзбуршкој царевини „сви народи могу да остваре свој цивилизацијски искорак. А да би српски народ то учинио, морало му се 'помоћи' да се ослободи својих заблуда. Када је култура у питању, као највећа препрека укључењу српског народа у цивилизацију видело се његово писмо - ћирилица” (Ђорђевић 2014: 7). „Поред коришћења латинице, постало је обавезно учење немачког и мађарског језика. Наставнички кадар је замењен, у понеким случајевима чак аустроугарским подофицирима (капларима). Али, Аустроугарска је целокупни рад окупационе управе у Србији представљала као 'цивилизаторски'” (Радојевић/Димић 2014: 204).

На челу окупационих области које су припале Бугарској био је војни гувернер, а власт су имали искључиво Бугари. „Са задатком да спроведу бугаризацију доведени су и бугарски учитељи. У школама, које су биле обавезне за српску децу, настава је извођена искључиво на бугарском језику. Бугарској пропаганди била је подређена и настава историје и географије. Научници су добили задатак да 'докажу’ етничку, језичку, историјску и географску припадност 'бугарског Поморавља' и Македоније матици Бугарској, а просветни радници да о томе предају у школи. У функцији пропаганде били су штампа и културна друштва којима је био допуштен рад. На удару су били национална свест и идентитет српског народа. Како би српска интелигенција била уништена, похапшени су домаћи наставници и професори, свештеници, чиновници и политичари. Многи од њих били су одмах погубљени, најчешће на врло свиреп начин. У том погледу бугарска окупација била је бруталнија од аустроугарске, јер су злочини чињени стално и у великом броју" (Радојевић/Димић 2014: 204).

Чак је и „употреба српских личних имена, натписа и језика забратена, а уџбеници и књиге на српском језику систематски су уништавани. Срби су добијали нова презимена, а новорођена деца бугарска имена. Српске цркве су најпре оскрнављене, да би у њих потом били доведени бугарски свештеници. Прослава крсне славе је забранена" (Радојевић/Димић 2014: 205).

И Аустроугарска и Бугарска су на окупираним српским територијама проводиле терор, забраниле су ћирилицу, али тај терор је ипак био кудикамо већи на територијама под бугарском управом, што потврђује и податак да су „аустроугарски чиновници у Беч слали извештаје о 'срећи' коју показују Срби који се налазе у аустроугарској, а не у бугарској окупационој области” (Радојевић/Димић 2014: 247). 


\section{3. ТОКОВИ ЈЕЗИКА КАО ДА РАТА НЕМА}

Иако је ћирилица званично била забрањена и прогнана из употребе у свим земљама које су биле под Аустроугарском - а подсјетимо се да су то већ скраја 1915. и почетка 1916. године биле и Хрватска, и Босна и Херцеговина и Србија и Црна Гора - ипак је и у тим временима било не само употребе српске ћирилице него чак и штампаних уџбеника српскога језика. Тако је Милан Решетар, тадашњи професор Бечког универзитета, 1916. у јеку рата, издао у Загребу Elementar-Grammatik der kroatischen (serbischen) Sprache, латиницом, односно Elementar-Grammatikderserbischen (kroatischen) Sprache, са текстовима на ћирилици. То је било вријеме кад се готово ништа није смјело штампати ћирилицом, нити сам језик именовати српским именом, будући да су аустроугарске власти и српско име језика и његово ћириличко писмо биле забраниле, сматрајући их „актом непријатељства” према Монархији. „Дупло именовање “потпуно јединственог српскохрватског језика’ Решетар је, како каже, увео из педагошко-методичких разлога. Оба су издања 'потпуно идентична' јер је, у питању 'потпуна идентичност језика" (Окука 2006: 138; Ивић 1998: 305).

А исте, 1916. године у Сарајеву је изашла и Граматика српско-хрватског језика за средње школе Босне и Херцеговине Николе Симића (Окука 2006: 97, 138). Интересантно је да је та Симићева граматика у свом трећем издању 1923. године изашла с промијењеним називом језика у „српски или хрватски”. ${ }^{3}$

\section{4. СРПСКИ ЈЕЗИК И РАТНИ ПОЛИТИЧКИ ЦИЉЕВИ СРБИЈЕ}

Рат који је мјесец дана послије атентата у Сарајеву, 28. јула 1914. године, објавила Аустроугарска је „истовремено, отворио могућност да историјска шанса уједињења Јужних Словена, као питање опстанка у будућности, буде претворено у реалност. Те две саставнице - одбрана државне независности и тежња за формирањем шире заједнице - чиниле су суштину идеологије српске државе 1914. године” (Радојевић/Димић 2014: 143).

Државни програм, како пишу М. Радојевић и Љ. Димић (2014: 144145) прошао је кроз више фаза. На самом почетку рата најбитнија је била „српска идеја” и „одбрана Отаџбине”. Већ након неколика мјесеца, током љета и јесени почело се говорити о српском уједиғењу као ратном

${ }^{3}$ Nikola Simić, Gramatika srpskoga ili hrvatskogajezika: za srednje škole. 3. popravljeno izd. Sarajevo: Zemaljska štamparija, 1923. 145, IV str. 
циљь. Почетком септембра 1914. године, у круговима блиским двору и влади формулисан је став да се „од Србије створи једна јака југозападна словенска држава у чији би састав ушли и сви Срби и сви Хрвати и сви Словенци".

У дефинитивном уобличењу државног програма Србије најзначајнију улогу имала је Нишка декларација, која је на неки начин значила прекретницу у српској државној политици. „Влада Краљевине Србије, образована проширивањем радикалског кабинета и састављена од представника највећих српских грађанских странака, дала је 7. децембра 1914. године у народном представништву изјаву у којој је речено да ће у времену које долази све своје силе ставити 'у службу велике ствари СРПСКЕ ДРЖАВЕ и Српско-Хрватског и Словеначког Племена'. Уверена 'у решеност целог српског народа да истраје у светој борби за одбрану свог огњишта и своје слободе', истакла је 'као свој најглавнији и у овим судбоносним тренуцима једини задатак да обезбеди успешан свршетак овог великог војевања које је, у тренутку кад је започето, постало уједно борбом за ослобођене и уједиюене све наше неослобођене браће Срба, Хрвата и Словенаца” (Радојевић/Димић 2014: 146). Тако се „од програма који је предвиђао ослобађање и уједињење делова суседних земаља у којима живе Срби, коракнуло потом ка општејугословенском уједињењу" (Радојевић/Димић 2014: 147).

Тако је усред рата српска влада и српска политичка елита „идеју о 'три племена једног народа’ уградила у темеље своје политичке филозофије и будуће државности како би путем ње превладала бројне политичке, верске, економске, културне, историјске, националне и менталистичке разлике. Истовремено, њоме су изражавана настојања да Србија од мале прерасте у велику државу, а Срби, као полицентричан народ, буду окупљени у границама јединствене и независне државе. Том циљу жртвовани су идентитет српске државе и юена државност" (Радојевић/ Димић 2014: 147).

Савезници, међутим, нису с одобравањем, него ћутањем, реаговали на појаву Нишке декларације. Једино је подршка Русије била несумњива. Зато је српска влада Николе Пашића сматрала да треба провести пропагандну акцију како би се са ставовима из декларације не само упознале државе Антанте него и добила њихова подршка. Тај пропагандни посао најбоље је могао урадити Југословенски одбор, који је израстао из групе научника коју је окупила српска влада 29. августа 1914, а то су: Љуба Јовановић, Александар Белић, Јован Цвијић, Никола Стојановић, Мирко Латас и Слободан Јовановић. „Тај одбор је, после састанака у Фиренци и Паризу, коначно смештен у Лондон 9. маја 1915. са Антом Трумбићем 
као председником. Буџет одбора је састављен од две трећине фонда из српске владе и једне трећине (отприлике) из других извора" (Екмечић 2007:350).

Показаће се, међутим, да је, управо захваљујући Трумбићу, постојала битна разлика у схватању Пашићевог и одборовог југословенства. Јер, „докле је г. Пашић постављао питање нашег народног јединства на широку основицу опште и најпрече потребе народне, дотле је то питање Југословенски Одбор постављао на основицу посебних хрватских унутрашњих интереса, на основицу претходног и нарочито условљеног споразума Срба и Хрвата” (Ђорђевић 1922: 32), тако да је њихов основни циљ, „идеја водиља до свршетка рата”, био стварање „југословенског народа" (Ђорђевић 1991: 32).

И управо ће коначно уобличење југословенске идеје и на њој засноване заједничке државе, заједно са српском Пашићевом владом, направити Југословенски одбор на Крфској конференцији која је одржана од 5. јуна до 27. јула 1917. године. Наиме, на Крфу је тада дошло до првих званичних разговора представника српске владе и Југословенског одбора око унутрашњег уређења будуће државе.

„На супротстављеним ставовима око унитаристичког или федералистичког облика унутрашњег уређења преламали су се погледи о националном питању, суштини националног јединства 'троплеменог народа' Срба, Хрвата и Словенаца, садржини националног унитаризма, облику државног уређења, основама провизоријума. Никола Пашић је био убеђен да у датим историјским околностима будућност има једино јака унитарна и централистички уређена држава. Дозвољавао је могућност да одредбе о локалној самоуправи, које је садржао Устав Краљевине Србије, унеколико буду промењене и примењене на целој територији будуће државе. Одбацујући федералистичко уређење као слабо и краткотрајно, саглашавао се да опстану посебности до којих су држали Хрвати, попуm имена, писма и амблема, али не и постојећа аутономија. У својих тринаест тачака Крфска декларација је представила принципе унутрашњег уређења будуће југословенске заједнице. Држава је требало да се зове Краљевина Срба, Хрвата и Словенаца и да буде слободна, независна, уставна, демократска и парламентарна монархија на челу са династијом Карађорђевић. Њени државни симболи - грб, застава, круна - требало је да буду заједнички и да као такви симболизују јединство, али и да буду састављени из посебних националних амблема" (Радојевић/Димић 2014: 251-252).

У декларацији се „поново и најодсудније наглашава да је овај наш троимени народ један и исти по крви, по језику говорном и писаном, 
по осећајима свога јединства, по континуитету и целини територије, на којој неподвојено живи, и по животним интересима свога националнога опстанка и свестранога развитка свога моралног и материјалног живота", при чему су изједначене 'православна, римокатоличка и мухамеданска вероисповест"' (Екмечић 2007: 363).

Током рата, међутим, ни Аустроугарска није сједјела скрштених руку. И она је тежила придобијању југословенских народа, стварањем свог југословенског програма.

„У страху да ће крај рата донети ветрове разарања хабзбуршке државе, сви су политички фактори у њој, а на првом месту католичка црква и њене организације, настојали да се побрину за лек, пре него што за њега буде касно. Један план хабзбуршког цара о претварању двојне, аустроугарске федерације у федерацију седам националних јединица, о коме су британске уходе биле обавештене у фебруару 1918, стваран је знатно раније. Држава би била састављена од немачке (Аустрија) јединке, мађарске, чехословачке, румунске (Трансилванија), пољске (Галиција), италијанске (Трст и залеђе) и једне југословенске. Идеја о једној Југославији у католичкој Средњој Европи је постојала и раније. 'Тријализам одоздо' 1903. дело је престолонаследника Франца Фердинанда и његовог круга у цркви и војсци. 'Југословенски клуб' у аустријском парламенту је 30. маја 1917. објавио декларацију о потреби стварања једне унутрашње државе Словенаца, Хрвата и Срба 'под жезлом Хабзбуршко-Лоренске династије’. У том клубу нису били представљени посланици из Хрватске јер по дуалистичком систему два парламента контактирају само преко 'делегација', које се годишње састају да изгласају заједнички буџет. Југословенски клуб је водио свештеник Антон Корошец. У том клубу је било 23 словеначка посланика, из четири словеначке покрајине, 12 хрватских из Далмације и Истре и 2 Србина. Било је од почетка замишљено да ово буде унитарна држава на основама хрватског историјског права, то јест са свим елементима унутрашње државности у којој се Хрватска развијала од XII века. Поред политичких установа и правних основа, Хрватска би тој држави дала и јединствени језик” (Екмечић 2007: 359).

Дакле, у име „Југословенског посланичког клуба”, у бечком парламенту декларацију је прочитао др Антон Корошец, 30. маја 1917. године - због чега се она и зове мајска декларација - у којој се захтијевало „да се све земље у Аустро-Угарској, на којима живе Срби, Хрвати и Словенци, на темељу народног начела и хрватског државног права, уједине у једно самостално државно тело „под жезлом Хабзбуршко-Лоренске династије” (Ђорђевић 1922: 127). Интересантно је да су се „све хрватске и словеначке странке придружиле горњој декларацији свом душом, доносећи 
изјаве и резолуције у истом духу и смислу: све су изјављивале да желе 'Југославију' под жезлом Хабзбуршко-Лоренске династије, и све су ту бормулу најсрдачније прихватале"4 (Ђорђевић 1922: 127).

Као што се види, у размаку од два мјесеца (30. мај и 27. јули) 1917. године донесене су двије декларације, обје с југословенском идејом као основом, једна Мајска, а друга Крфска, једна с Аустроугарском, а друга са Србијом као иницијатором и проводитељем.

\section{5. ЦВИЈИТЕВА И БЕЛИТЕВА УЛОГА У ОСТВАРЕЊУ СРПСКОГ ЈУГОСЛОВЕНСКОГ ПРОГРАМА}

Већ смо рекли да је српска Пашићева влада око југословенског програма окупила научнике који су ту идеју могли да бране поузданим аргументима. Уосталом „круг српског јавног мишљења који је подржавао званичан југословенски ратни циљ српске владе у свом основном језгру био је састављен од универзитетских и средњошколских професора" (Екмечић 2014: 131). „Тај професорски круг по традицији српске модерне политике био је врло утицајан на државне врхове, а кад Јован Цвијић држи 1907. године инструктивно предавање о 'националном роду', међу юеговом публиком слуша га из првог реда српски крал" (Екмечић 2014: 134). С образложењем југословенства као српске ратне идеје најприје излази историчар С. Станојевић у чланку „Наше претензије” од 10/23 децембра 1914, а потом и у књижици Шта хоће Србија (Ниш, 1915), гдје тезу о „троименом народу” образлаже „историјском чињеницом да су Срби, Хрвати и Словенци један народ који се у раном средњем вијеку раздвојио, а у новије вријеме све више разилазио због утицаја и власти страних сила: 'Срби, Хрвати и Словенци, један су народ по пореклу и по језику. Срби и Хрвати су потпуно идентични, а од Словенаца их деле сасвим незнатне разлике” (Екмечић 2014: 132). Станојевић се, међутим, не сматра „перјаницом” одбране југословенства као политичког ратног циља српске владе. Ту су улогу имали Јован Цвијић и Александар Белић.

Наиме, „Цвијић је још у години 1914. радио на брошурама насловљеним 'Јединство Југословена' где је, на основу својих дотадашњих теренских истраживања настојао да образложи да географска целина Југославије (подељена у три природно и економски нераздвојна појаса) заједно са сродношћу језика и народа (сврстаном у неколико етнопсихичких група насталих миграцијама и асимилацијом становништва) чине

${ }^{4}$ Оба курзивна истицања у цитатима су изворна, у самоме тексту Ђорђевићевом. 
полазну основу за тумачење јединства Јужних Словена" (Пишев 2013: 129). Цвијић ће у опширној расправи писаној за потребе српске владе Јединство и психичк типови динарских ужних Словена нагласити да сам географски фактор, поред свега осталога што је њена модерна историја показала, одређује Србију да буде центар Југославије: „По географском положају, по пластици и према својој етничкој композицији Србија је предестинирана да веже или споји западне и источне југословенске земље и племена" (Екмечић 2014: 136).

Од Цвијићевог научног доприноса образложењу идеје југословенства по својој непосредној политичкој примјени чак је значајнија научна студија Александра Белића Србија и јужнословенско питаюе, која је такође штампана „као рукопис у ограниченом тиражу, у Нишу 1915. године”. „Знање које сумира ово дјело јесте сљедеће: етничка група је заједница која има једно поријекло. Оно се углавном посматра као поријекло крвног сродства, а једини мјеродаван критеријум који човјеку стоји на располагању да по њему одреди етничку групу јесте језик" (Екмечић 2014: 137).

Зашто се питање језика узима за основно при одређењу статуса српског и/или српскохрватског питања уопште, одговор даје сам Белић, констатацијом да је „језик несумњиво најјаснији знак једне етничке целине. Традиције, обичаји, историска прошлост и све друго не говоре никад тако поуздано о блиским везама по пореклу, по крви - као језик. Само је увек питање, који се критеријум узима за одређење целокупности једног језика” (Белић 1991: 15). Посматран из данашње перспективе, Белићев критеријум „целокупности једнога језика”, овдје српскога или српскохрватскога, више је него споран, више је политички неголи лингвистички, више ради одбране прокламованих циљева Владе Србије, неголи одраз научних чињеница и на њима темељених истина. Јединство српскохрватског језика Белић, наиме, образлаже на сљедећи начин: „Како штокавским дијалектом говоре и Хрвати и Срби, а чакавским само Хрвати, то ја називом српскохрватски језик не означујем штокавскочакавске дијалекте него један језик по пореклу, чијим данашњим дијалектима говоре они који се називају Србима и Хрватима. Из овога се види да је назив српскохрватски језик врло релативне вредности. Ми њиме називамо групу оних народних говора који при поређењу са оближњим словенским језицима чине по свом, пореклу целину. Тако чакавско-цтокавски заједнички дијалекат стоји према словеначком језику" (Белић 1991: 20). На основу тако издвојенога и образложенога језичког критеријума Белић закључује да „у национално-језичком правцу Босна и Херцеговина са Славонијом, Хрватском и Далмацијом чине 
један комплекс, који једним својим делом улази дубоко у данашњу Краљевину Србију и потпунце обухвата Црну Гору” (Белић 1991: 30).

Тако Белић, држећи се добрано насилно изведеног „штокавско-чакавског јединства” као темељног критеријума, „Србе и Хрвате није сматрао у духу времена и пре свега научних уверења о јединственом језику Срба и Хрвата - за два народа, већ као два племена једног истог народа, слично схватањима и размишљањима и неколико других истакнутих Срба и Хрвата тога времена (Ј. Цвијић, Ст. Новаковић, Валтазар Богишић, Иван Мештровић, Ватрослав Јагић, Ј. Скерлић и др.). 'То нису - цитира Белића В. Стојанчевић - два дела једне целине са засебним називима, него два назива исте целине”" (Стојанчевић 1991: 134).

„На начин како је 1914-15. говорио Белић говорили су сви југословенски оријентисани интелектуалци онога времена", што је више него довољан аргумент закључку да су „принцип југословенског уједињења створили професори, а не подофицири” (Екмечић 2014: 140).

\section{6. ЗАКЉУЧАК}

На свим српским просторима, у свим државама српскога народа - у Хрватској, Босни и Херцеговини, Црној Гори и Србији - током Првога свјетскога рата били су прогоњени и прогнани не само ћирилица и српски језик, него и српско име уопште.

Тако је већ 3. октобра 1914. Земаљска влада у Хрватској укинула учење ћирилице у јавним основним школама, док је Наредбом школским властима од 5. новембра 1914. Земаљска влада у Загребу укинула назив хрватски или српски језик промијенивши га у хрватски језик, да би новом наредбом Владе од 3. јануара 1915. у Хрватској ћирилица била укинута и у раду администрације.

У Босни и Хериеговини ћирилица је укинута 10. новембра 1915. Наредбом Земаљске владе у Сарајеву, Земаљска влада укинула је и Уредбу о аутономији иркве и школе у Босни и Хериеговини, при чему је назив цркве из српско-православна промијенила у источно-православна, али је назив језика остао српско-хрватски. Иначе, свуда гдје је то било могуће као неподобан одстрањиван је термин „српски”.

Након окупације Црне Горе 1916. године аустријска власт је наредбом генералног гувернера Виктора Вебера од 18. септембра 1916. забранила употребу ћирилице у школама, установама и поштанском саобраћају. Аустроугарске власти нису у Црној Гори укинуле само ћирилицу, него су у наставним плановима и програмима за основну школу из назива свих предмета избацили атрибут „српски”, тако да је српски језик окупатор 
замијенио матерюим језиком, српску историју - историјом, ирквенословенско читане - читанем.

У Србији је 1. априла 1916. године потписан уговор којим је утврђена демаркациона линија између аустроугарске и бугарске команде. Неколика мјесеца након тога аустријске власти на свом дијелу окупиране Србије забраниле су употребу ћирилице, као писма које је сматрано дијелом српског националног идентитета, и препреком остварења цивилизацијског искорака Срба. Одлуку о забрани ћирилице у јавној употреби донио је Војни генерални гувернеман за Србију 12. јуна 1916. године. На дијелу територије Србије којим су владали Бугари на удару су били национална свијест и идентитет српског народа. Настава је извођена искључиво на бугарском језику. Забрањена је употреба српских личних имена, натписа и српскога језика. Срби су добијали нова презимена, а новорођена дјеца бугарска имена. Прослава крсне славе је забранена.

Док су, дакле, на свим српским просторима прогнани српски језик и ћирилица, српска влада и Југословенски одбор, који је она сама формирала - као основни ратни циљ истичу ослобођење и уједињење све наше неослобођене браће Срба, Хрвата и Словенаца, јер они представљају 'троимени', али 'једноплемени' народ. Српској националној идеји претпостављена је идеја југословенства, за коју је жртвован идентитет српске државе и њена државност. При том је жртвована и србистичка филолошка Вуков(ск)а парадигма, а са њом посредно и ћирилица.

У Крфској декларацији удовољило се захтјеву Хрвата да се у новој југословенској држави не укидају посебности попут имена, пuсма и амблема, и вјерских разлика. Из тога се види да су већ тада Хрвати заправо бранили не само име хрватског језика, него и латиницу, бојећи се да ће у парламентарној монархији на чијем челу је династија Карађорђевић ћирилица, као једино српско писмо са статусом националне идентитетске карактеристике, добити превласт. И инсистирање на вјерским разликама у Крфској декларација било је у хрватском интересу, јер је познато да је „верски моменат у националној идеологији код Хрвата играо претежну улогу, док је код Срба било обрнуто. Србину је увек било прече Српство од вере, а Хрвату вера од Хрватства" (Ђорђевић 1922: 130). Но и поред тога, српска је влада и српска инетелектуална елита током Првога свјетског рата српству претпоставила југословенство.

У одбрану идеје југословенства и на њој утемељене заједничке државе ангажовани су најзначајнији тадашњи српски научници, међу којима се по свом утицају издвајају Јован Цвијић и Александар Белић. Белић је својом књигом Србија и јужнословенско питане највише 
допринио укидању србистичке парадигме за рачун југословенске сербокроатистичке, а заправо кроатистичке. Јер, у праву је М. Екмечић кад каже да је ово српско југословенство „директан наставак илирства из прве половине XIX вијека, које тек овдје у Србији добија своју праву афирмацију и свој највећи врхунац" (Екмечић 2014: 133). Посљедице и илирства и југословенства данас су добро знане: оба су покрета била у корист Хрвата, а на српску штету. Показало се тако да је „циљ рата јачи од рата" (Екмечић 2014: 496), па самим тим и остварење политичког циља значајније од саме побједе у рату.

\section{ЛИТЕРАТУРА}

Белић 1991: Александар Белић, Србија и јужнословенско питаюе, Београд: Библиотека града Београда.

Ђорђевић 1922: Милан П. Ђорђевић, Србија и Југословени за време рата 1914-1918, Београд.

Ђорђевић 2014: Бојан Ђорђевић, „Музе нису ућутале: културни живот Срба током Великог рата у огледалу тадашње штампе”, у: Бојан Ђорђевић, Драгана Грујић, Гордана Ђоковић, Летопис културног живота током Великог рата: 1916-1918, Београд: Институт за књижевност и уметност, Нови Сад: Матица српска.

Екмечић 2007: Милорад Екмечић, Дуго кретаюе између клаға и ораға, Београд: Завод за уџбенике.

Екмечић 2014: Милорад Екмечић, Ратни иильеви Србије 1914, Београд Гацко: Филип Вишњић, СПКД Просвјета.

Ивић 1971: Павле Ивић, Српски народ и юегов језик, Београд: Српска књижевна задруга.

Ивић 1998: Павле Ивић, Преглед историје српског језика, Нови Сад - Сремски Карловци: Издавачка књижарница Зорана Стојановића.

Караџић 1977: Вук Стеф. Караџић, „Срби сви и свуда”, у: Срби и юихов језик: хрестоматија, (прир. П. Милосављевић), Приштина: Народна и универзитетска библиотека, 125-141.

Матовић 2013: Веселин Матовић, Ћирилица и татиногорица, ПодгорицаНикшић: Књижевна задруга Српског народног вијећа.

Окука 2006: Miloš Okuka, Srpski na kriznom putu, Istočno Sarajevo: Zavod za udžbenike i nastavna sredstva. 
Пишев 2013: Marko Pišev, Politička etnografija i srpska intelektualna elita u vreme stvaranja Jugoslavije 1914-1919: Slučaj Jovana Cvijića, Beograd: Filozofski fakultet.

Радојевић/Димић 2014: Мира Радојевић, Љубодраг Димић, Србија у Великом рату 1914-1918, Београд: СКЗ - Београдски форум за свет равноправних.

Стојанчевић 1991: Владимир Стојанчевић, „Александар Белић и његова студија 'Србија и јужнословенско питање”, поговор књизи А. Белића, Србија и јужнословенско питаюе, Београд: Библиотека града Београда, 133-138.

Томашевић 2011: Маја Томашевић, Баюалучки велеиздајнички проиес, Бања Лука: Бесједа - Гимназија.

\author{
Miloš Kovačević \\ THE LANGUAGE AND THE SERBIAN CYRILLIC ALPHABET \\ DURING THE FIRST WORLD WAR
}

Summary

The paper analyzes the events concerning the Serbian language and the Serbian Cyrilic alphabet during the First World War not only in Serbia but also in other areas / territories of the Serbian language- Croatia, Bosnia and Herzegovina and Monte Negro. The political events concerning the Serbian language caused by the outbreak of the First World War are analyzed, such as the Austria-Hungarian prohibition of the use of the Cyrilic alphabet in all the areas / territories of the Serbian language, and then on the territories under the rule of Austria-Hungary and the prohibition of the use of the Serbian name in the very name of the language.

The paper also points to the linguistic contributions to the Serbian language during the First World War; thus a special attention is given to the role of the Serbian language grammars published during the Great War in different territories in the Serbian language, but also in German (grammars by Milan Resetar and Nikola Simic) on one hand, and on the other hand, the linguistic studies by Aleksandar Belic from 1915 about the Serbian language as the foundation criteria of the Serbian as the Serbo-Croatian national question / issue.

The paper also shows to what extent the First World War has contributed to forcing the Serbo-Croatian as the only " correct / right " Serbian philological paradigm. 